

Edukatif : Jurnal Ilmu Pendidikan Volume 3 Nomor 4 Tahun 2021 Halm 1808 - 1820

EDUKATIF: JURNAL ILMU PENDIDIKAN

Research \& Learning in Education

https://edukatif.org/index.php/edukatif/index



\title{
Pengetahuan, Persepsi dan Sikap Masyarakat Terhadap Keinginan untuk melakukan Konservasi Hewan Liar yang Terancam Punah
}

\author{
Mutiara Selni $^{1 凶}$, Fachruddin M. Mangunjaya ${ }^{2}$, Gugah Praharawati $^{3}$, Yeremiah Rubin \\ Tjamin $^{4}$, Bahagia ${ }^{5}$ \\ Universitas Nasional Jakarta, Indonesia ${ }^{1,2,4}$ \\ Institute Pertanian Bogor, Indonesia ${ }^{3}$ \\ Universitas Ibn Khaldun Bogor, Indonesia ${ }^{5}$ \\ E-mail : Mutiaraselni97@gmail.com ${ }^{1}$, fmangunjaya@ @ivitas.unas.ac.id $^{2}$, yeremiahrt@gmail.com ${ }^{4}$, \\ bahagiagia59@yahoo.co.id ${ }^{5}$
}

\begin{abstract}
Abstrak
Indonesia merupakan negara kepulauan yang memiliki keanekaragaman hayati dengan berbagai macam jenis flora dan fauna. Salah satunya adalah harimau sumatera (Panthera tigris sumatrae) yang keberadaan populasinya masuk ke dalam kategori status kritis terancam punah (critically endangered). Penelitian ini bertujuan untuk mengetahui pengaruh dari sosialisasi fatwa MUI terhadap pengetahuan, persepsi dan sikap masyarakat melalui ceramah mengenai ilmu konservasi yang di sampaikan oleh ustadz yang sebelumnya telah mengikuti pelatihan di kawasan Bukit Rimbang-Baling. Metode penelitian yang digunakan yaitu metode kuantitatif dengan alat uji statistik untuk mengetahui pengaruh antara variabel $\mathrm{X}$ dan $\mathrm{Y}$. Metode pengambilan sampel yaitu menggunakan purposive sampling. Sedangkan pengumpulan data dilapangan menggunakan instrumen penelitian berupa kuisioner yang dibagikan kepada masyarakat. Hasil dari penelitian ini menunjukan pengetahuan memiliki hubungan dengan niat aksi untuk konservasi lingkungan. Demikian hal dengan sikap dan persepsi memiliki hubungan terhadap niat untuk melakukan konservasi lingkungan. Penelitian ini dapat disimpulkan bahwa pengetahuan, persepsi dan sikap memiliki hubungan terhadap niat untuk melakukan kegiatan konservasi lingkungan.
\end{abstract}

Kata kunci :Fatwa, konservasi, pengetahuan, persepsi, sikap.

\begin{abstract}
Abstrak
Indonesia is an archipelagic country that has biodiversity with various types of flora and fauna. One of them is the Sumatran tiger (Panthera tigris sumatrae) whose population is categorized as critically endangered. This study aims to determine the effect of the socialization of the MUI fatwa on the knowledge, perceptions and attitudes of the community through lectures on conservation science delivered by Ustadz who had previously attended training in the Bukit Rimbang-Baling area. The research method used is a quantitative method with statistical test equipment to determine the effect between variables $X$ and $Y$. The sampling method is using purposive sampling. Meanwhile, data collection in the field used research instruments in the form of questionnaires which were distributed to the public. The results of this study show that knowledge has a relationship with action intentions for environmental conservation. Likewise, attitudes and perceptions have a relationship with the intention to conserve the environment. This study can be concluded that knowledge, perceptions and attitudes have a relationship with the intention to carry out environmental conservation activities.
\end{abstract}

Keywords: Conservation, Knowledge, Perception and Attitude.

Copyright (c) 2021 Mutiara Selni, Fachruddin M. Mangunjaya, Gugah Praharawati, Yeremiah Rubin Tjamin, Bahagia

$\triangle$ Corresponding author

Email : Mutiaraselni97@gmail.com

DOI : https://doi.org/10.31004/edukatif.v3i4.579 
1809 Pengetahuan, Persepsi dan Sikap Masyarakat Terhadap Keinginan untuk melakukan Konservasi Hewan Liar yang Terancam Punah - Mutiara Selni , Fachruddin M. Mangunjaya, Gugah Praharawati, Yeremiah Rubin Tjamin, Bahagia

DOI: https://doi.org/10.31004/edukatif.v3i4.579

\section{PENDAHULUAN}

Indonesia sebagai negara kepulauan memiliki luas hampir sepertiga (32\%) dari hutan hujan di Asia Selatan dan Tenggara (FAO \& JRC, 2012). Hutan hujan ini memiliki berbagai peran penting termasuk menyediakan layanan ekosistem untuk memelihara keanekaragaman hayati dan mengendalikan perubahan iklim (Kremen et al., 2000). Sayangnya, tingkat deforestasi hutan di Indonesia dan khususnya Riau sangat tinggi, terutama di luar kawasan lindung yang menjadikan Indonesia sebagai penghasil emisi karbon terbesar ketiga di dunia (Measey, 2010).

Indonesia memiliki keanekaragaman hayati dengan berbagai jenis flora dan fauna yang dilindungi. Salah satu jenis fauna yang terancam punah baik habitat maupun jumlah populasinya yaitu harimau. Negeri ini pernah memiliki tiga dari delapan jenis harimau yang ada di dunia, namun dua di antaranya yaitu harimau jawa (Panthera tigris sondaica) dan harimau bali (Panthera tigris balica) telah dinyatakan punah, masingmasing pada tahun 1940 dan 1980. Saat ini yang tersisa hanya jenis harimau sumatera (Panthera tigris sumatrae). Sejak tahun 1996 The International Unionfor the Conservation of Nature and Natural Resources/The World Conservation Union (IUCN) mengkategorikan harimau sumatera sebagai satwa kritis terancam punah (Critically Endangered) dan Convention on International Trade in Endangered Species of Wild Fauna and Flora (CITES) juga mengkategorikan satwa liar harimau sumatera masuk ke dalam status appendix I yang melarang adanya perburuan dan perdagangan satwa (IUCN, 2016).

Populasi harimau sumatera saat ini mengalami penurunan yang cukup drastis dan keberadaannya semakin sulit ditemukan di alam bebas. Berkurangnya populasi harimau Sumatera disebabkan banyak faktor seperti penyempitan areal hutan yang merupakan habitat asli mereka yang sudah dikonversi menjadi lahan perkebunan dan industri (Sriyanto, n.d.). Perkembangan konflik terhadap satwa liar dengan masyarakat juga terus meningkat bahkan sangat memprihatinkan. Penanggulangan konflik satwa liar diantaranya melalui pengembangan pendidikan dan pelatihan yang berbasis wawasan konservasi sumber daya alam terhadap masyarakat setempat (Hasiholan dan Widyaiswara, 2011).

Habitat harimau terdapat di bagian tengah Sumatera yang menjadi jalur koridor utama perlintasan harimau sumatera. Lanskap ini menciptakan banyak relung yang sering disinggahi oleh berbagai satwa liar, sehingga kawasan ini memiliki keanekaragaman hayati yang sangat tinggi. Salah satu dari kawasan tersebut adalah kawasan bentang alam Rimbang-Baling yang memiliki luas sekitar 142.000 ha. Bentang alam ini mencakup beberapa kawasan konservasi yaitu Suaka Margasatwa Bukit Rimbang-Bukit Baling dan Cagar Alam Bukit Bungkuk serta kawasan lindung yaitu Hutan Lindung Bukit Batabuh (WWF, 2016).

Suaka Margasatwa Bukit Rimbang-Bukit Baling merupakan kawasan konservasi di Provinsi Riau yang berbatasan langsung dengan Sumatera Barat, Termasuk di dalam wilayah administrasi Kecamatan Singingi Kabupaten Kuantan Singingi, dan Kecamatan Kampar Kiri Hulu, Kabupaten Kampar. Wilayahnya berada di daerah hulu dari dua Sub daerah aliran sungai (DAS) yaitu sungai Subayang dan sungai Singingi yang merupakan sub DAS dari sungai Kampar (YAPEKA dan WWF, 2015).

Jumlah populasi harimau sumatera di Riau khususnya, di Suaka Margasatwa Rimbang-Baling diperkirakan mengalami penurunan setiap tahunnya. Keadaan ini dipicu oleh banyaknya permasalahan yang terjadi dalam kawasan Suaka Margasatwa yang saling terkait satu dengan yang lainnya. Kawasan RimbangBaling adalah sebuah kawasan konservasi dimana seharusnya tidak ada manusia ataupun aktivitas kehidupan masyarakat didalam kawasan tersebut. Kalau pun ada penduduk lokal yang mendiami suaka margasatwa diharapkan bisa hidup menyatu dengan alam. Suaka Margasatwa Rimbang-Baling terdapat ratusan penduduk yang menetap terlebih dahulu di kawasan tersebut. Seiring berjalan waktu, masyarakat semakin berkembang dan bertambah sehingga membutuhkan wilayah yang lebih luas lagi dan menambah aktivitas di sekitar kawasan Suaka Margasatwa (WWF, 2016). 
1810 Pengetahuan, Persepsi dan Sikap Masyarakat Terhadap Keinginan untuk melakukan Konservasi Hewan Liar yang Terancam Punah - Mutiara Selni , Fachruddin M. Mangunjaya, Gugah Praharawati, Yeremiah Rubin Tjamin, Bahagia

DOI: https://doi.org/10.31004/edukatif.v3i4.579

Menurut WWF, (2016) aktivitas penduduk di sekitar kawasan konservasi sangat mengancam keberadaan populasi satwa liar yang ada di Suaka Margasatwa Bukit Rimbang-Baling. Bekas penambangan yang ditinggal begitu saja mengakibatkan efek pencemaran sungai yang menimbulkan kerugian kepada masyarakat yang masih memanfaatkan sungai sebagai sumber kebutuhan hidup mereka. Alih fungsi lahan disekitar kawasan Suaka Margasatwa oleh perusahaan juga menjadi ancaman besar terhadap kawasan konservasi dikarenakan semakin terbukanya akses jalan bagi para pemburu harimau sumatera.

Masyarakat Bukit Rimbang-Baling merupakan salah satu contoh masyarakat yang menerapkan sistem adat khalifah yaitu dengan menjadikan nilai ajaran Islam sebagai kearifan lokal. Salah satu contoh kearifan lokal yang menjadi objek wisata adalah penerapan lubuk larangan. Kawasan ini ditetapkan sebagai satu kawasan dimana tidak diperbolehkan digunakan untuk keperluan sehari-hari untuk menjaga keseimbangan ekosistem sungai, sehingga hanya boleh digunakan sebagai sarana transportasi (Digdi et al., 2015). Selain itu, ada yang dinamakan kawasan larangan seperti hutan larangan pada beberapa masyarakat adat (Bahagia et al., 2020). Kawasan ini berperan sebagai menjaga lingkungan. Ditambah lagi dengan sistim bertani yang ramah lingkungan dengan tidak menanam padi intensif sehingga bisa menjaga lingkungan (Bahagia et al., 2020).

Penelitian pendekatan agama sebelumnya telah dilakukan oleh Clements et al. (2009) di Malaysia mengenai efektivitas khutbah jumat untuk pemahaman tentang pelestarian penyu belimbing. Kemudian McKay (2013) juga menerapkan metode yang sama pada saat bulan Ramadhan di pondok pesantren dan masjid dengan menyampaikan konten konservasi melalui ceramah agama sebelum shalat tarawih. Penelitian ini membuktikan pengajaran pendidikan agama berbasis konservasi lebih efektif dalam meningkatkan kesadaran untuk menjaga kelestarian alam. Agama Islam memiliki beberapa peranan penting yang ditaati oleh pengikutnya, diantaranya adalah Al-Quran, As Sunnah dan Ijma Ulama. Oleh karena itu MUI et al. (2017), mengeluarkan fatwa penting tentang pelestarian satwa langka untuk keseimbangan ekosistem guna mencegah terjadinya konflik dan perburuan satwa langka harimau sumatera Mangunjaya (2019). Fatwa menurut bahasa berarti petuah, nasihat, serta jawaban atas pertanyaan hukum. Tindakan memberi fatwa disebut futya atau ifta, sedangkan orang yang meminta fatwa disebut mustafti. Peminta fatwa bisa perorangan, lembaga ataupun siapa saja yang membutuhkan, orang yang memberi fatwa disebut mufti (I, 2011). Fatwa diharapkan dapat menjadi arahan serta petunjuk yang mampu mempengaruhi tingkat pengetahuan, persepsi dan sikap bagi umat Islam dalam menghadapi berbagai permasalahan yang terjadi khususnya seiring dengan perkembangan zaman (MUI et al., 2017).

Fatwa memiliki kedudukan sebagai hukum yang tidak mengikat tetapi mampu memperkuat kedudukan hukum yang ada karena fatwa dikeluarkan untuk menjawab suatu permasalahan sosial yang ada di masyarakat (Gade, 2015). Dalam upaya sosialisasi fatwa implementasi juga dilanjuti dengan melakukan penyebaran informasi baik secara nasional maupun internasional. Tindakan lanjutan fatwa MUI di Riau dilakukan dengan melakukan sosialisasi terhadap pemerintahan, pendidikan tingkat tinggi serta ulama setempat yang kemudian dilanjutkan dengan pelatihan para ustadz disekitar Bukit Rimbang-Bukit Baling (UNAS, 2021).

Menerapkan pendekatan agama untuk meningkatkan kesadaran lingkungan di kalangan umat Islam bukanlah konsep baru di Indonesia. Kesadaran konservasi yang dilakukan secara turun-temurun berawal dari ajaran agama yang lama kelamaan menjadi kebudayaan yang berbasis pada kearifan lokal dalam menjaga alam agar dapat terus digunakan secara sukarela sekaligus menjalankan perintah agama (Mangunjaya, 2011). Tahun 2014 Durrell Institute for Conservationand Ecology, proyek Darwin Initiative membentuk kemitraan bersama pemangku kepentingan lokal, nasional dan internasional yang bekerja dalam dua komunitas pedesaan dengan pendekatan agama Islam di Sumatera Barat, Padang (Mangunjaya \& McKay, 2012). Kegiatan proyek termasuk pemetaan partisipatif sistem penggunaan lahan dan hutan untuk melakukan penilaian keanekaragaman hayati, membuat pembibitan pohon dan sistem agroforest untuk merehabilitasi dan menghutankan kembali lahan terdegradasi. Lokal karya yang dipimpin oleh mitra dan proyek memberikan 
1811 Pengetahuan, Persepsi dan Sikap Masyarakat Terhadap Keinginan untuk melakukan Konservasi Hewan Liar yang Terancam Punah - Mutiara Selni , Fachruddin M. Mangunjaya, Gugah Praharawati, Yeremiah Rubin Tjamin, Bahagia

DOI: https://doi.org/10.31004/edukatif.v3i4.579

pelatihan bagi para pemimpin agama dan guru lokal tentang ajaran islam terhadap lingkungan dan meningkatkan kesadaran di masyarakat pedesaan dan perkotaan tentang dampak perubahan iklim dan pentingnya hutan untuk kehidupan.

Penelitian ini akan membahas tentang teori perilaku terencana atau TPB (Theory of Planned Behavior) yang merupakan pengembangan lebih lanjut dari teori perilaku beralasan (Theory of Reasoned Action). TPB adalah kerangka berpikir konseptual yang bertujuan untuk menjelaskan determinan perilaku tertentu. Penelitian sebelumnya telah menemukan pengetahuan dan sikap terhadap kegiatan konservasi lingkungan. Masyarakat memiliki pengetahuan terhadap keinginan untuk melakukan konservasi lingkungan. Demikian hal dengan sikap terhadap keinginan untuk konservasi lingkungan. Penelitian yang telah ditemukan berbeda dengan penelitian yang akan dilakukan. Pada penelitian ini masih mengambil variabel pengetahuan, persepsi dan sikap namun dikaitkan dengan fatwa ulama sebagai sumber untuk diujikan kepada masyarakat. Konsep fatwa ini membuat penelitian ini berbeda dengan penelitian sebelumnya sehingga diketahuo pengetahuan, sikap dan persepsi masyarakat terhadap fatwa ulama yang menjelaskan tentang kegiatan konservasi hewan liar yang terancam punah dan lingkungan.

Pada penelitian ini akan meneliti variabel pengetahuan, persepsi dan sikap diduga mempengaruhi niat konservasi terhadap satwa langka untuk keseimbangan ekosistem. Penelitian ini sangat penting karena kepunahan hewan dan kerusakan lingkungan dialam liar sebagai masalah terbesar manusia terutama fatwa ulama yang memiliki peran untuk menjaga lingkungan dengan melihat perspektif masyarakat. Oleh karena itu, peneliti akan melakukan penelitian lebih lanjut untuk mengetahui pengaruh pengetahuan, persepsi dan sikap terhadap niat konservasisatwa langka di kawasan Bukit Rimbang-Baling, Riau untuk menjaga keseimbangan ekosistem. Adapun tujuan penelitian ini diantaranya Untuk mengetahui tingkat pengetahuan terhadap niat aksi konservasi satwa langka di kawasan Bukit Rimbang-Baling, Riau, untuk mengetahui tingkat persepsi terhadap niat aksi konservasi satwa langka di kawasan Bukit Rimbang-Baling, Riau, untuk mengetahui tingkat sikap terhadap niat aksi konservasi satwa langka di kawasan Bukit Rimbang-Baling, Riau dan untuk mengetahui tingkat pengetahuan, persepsi dan sikap secara bersama terhadap niat aksi konservasi satwa langka dikawasan Bukit Rimbang-Baling, Riau.

\section{METODE PENELITIAN}

Penelitian dilakukan selama sepuluh hari pada tanggal 25 Mei - 4 Juni 2018 di kawasan Bukit Rimbang-Bukit Baling yang terdiri Sembilan desa intervensi dan non intervensi di tiga Kecamatan yaitu Kecamatan Kampar Kiri, Kecamatan Kampar Kiri Hulu dan Kecamatan Kuansing. Desa intervensi merupakan desa yang sebelumnya sudah diberikan sosialisasi pengetahuan tentang fatwa MUI oleh para ustadz yang sebelumnya sudah mendapatkan pelatihan oleh Majelis Ulama Indonesia (MUI) dan Pusat Pengajian Islam (PPI) (UNAS, 2021). Desa intervensi terdiri dari lima desa yaitu desa Padang Sawah, desa Tanjung Belit, desa Koto Baru, desa Aur Kuning, desa Sungai Paku. Desa non intervensi merupakan desa yang belum pernah disosialisasikan pengetahuan tentang fatwa MUI yang terdiri dari empat desa yaitu desa Gajah Betalut, desa Pangkalan Indarung, desa Gemma dan desa Domo (Gambar 1). Sampling dilakukan dengan mendatangi beberapa masjid di beberapa desa dan sebagian di ambil dengan langsung mendatangi rumah penduduk setempat. 
1812 Pengetahuan, Persepsi dan Sikap Masyarakat Terhadap Keinginan untuk melakukan Konservasi Hewan Liar yang Terancam Punah - Mutiara Selni , Fachruddin M. Mangunjaya, Gugah Praharawati, Yeremiah Rubin Tjamin, Bahagia

DOI: https://doi.org/10.31004/edukatif.v3i4.579

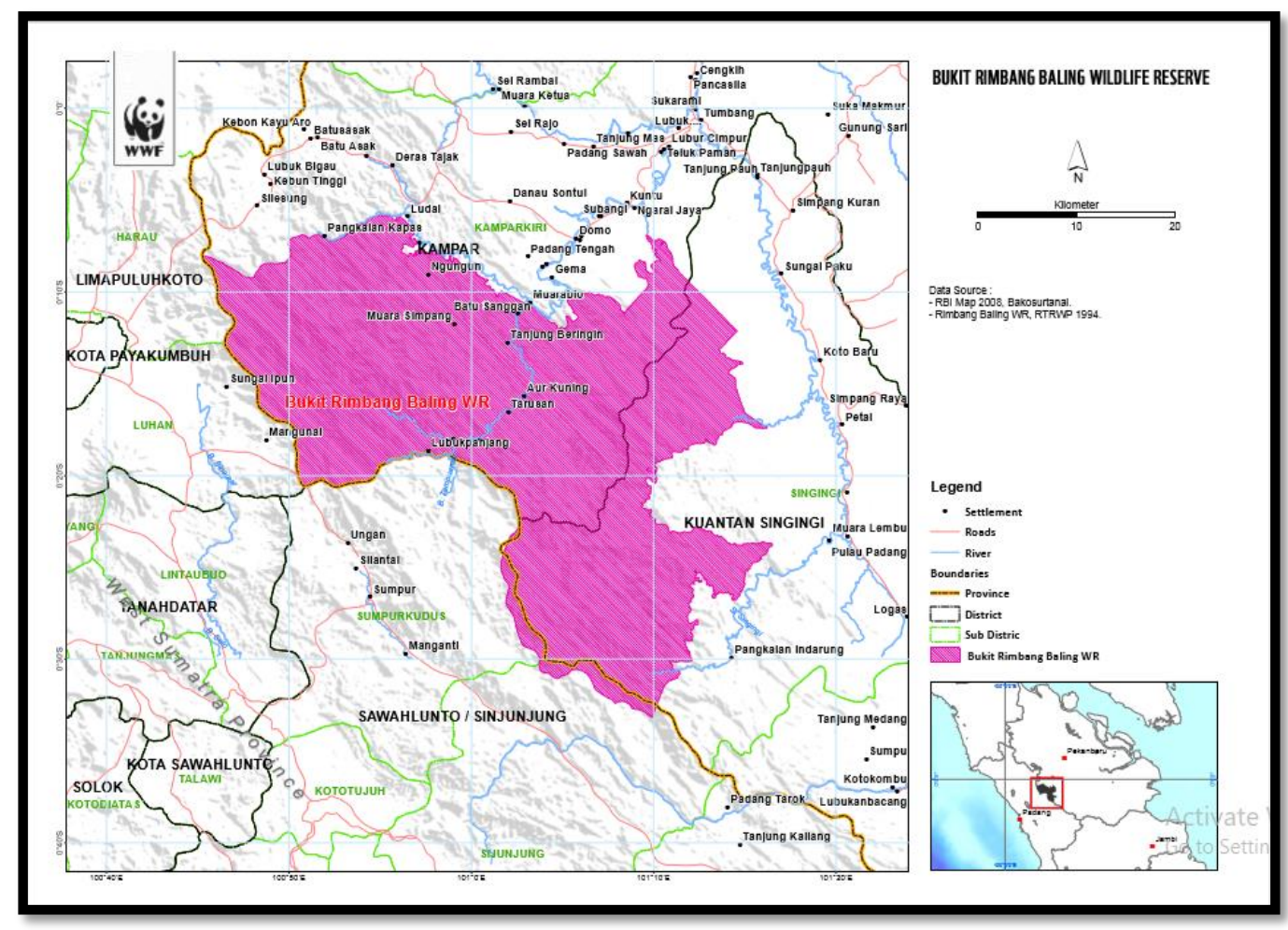

Gambar 1. Lokasi penelitian di kawasan Bukit Rimbang-Baling (WWF-Riau,2018)

Peralatan dan bahan yang digunakan adalah kuisioner skala Likert Allen \& Seaman (2007), Kamera handphone, literatur buku fatwa MUI No 04 tahun 2014 dan jurnal penelitian tentang fatwa. Definisi operasional merupakan penjabaran mengenai definisi dan indikator variabel-variabel yang akan diteliti pada penelitian ini. Dalam penelitian ini terdapat 2 macam variabel yang akan digunakan yaitu Variabel Bebas / Independen (X) dan Variabel independen yaitu variabel yang sering disebut sebagai variabel stimulus, pediator, antecendt. Dalam bahasa Indonesia sering disebut variabel bebas. Variabel bebas merupakan variabel yang mempengaruhi atau menjadi sebab timbulnya variabel dependen (terikat), Jadi variabel independen adalah variabel yang mempengaruhi (Sugiyono, 2010). Variabel Terikat / Dependen (Y) Variabel dependen, sering disebut sebagai variabel output, kriteria, konsekuen. Dalam bahasa Indonesia sering disebut sebagai variabel terikat. Variabel terikat merupakan variabel yang dipengaruhi atau yang menjadi akibat karena adanya variabel bebas (Sugiyono, 2010).

Tabel 1. Definisi Operasional Variabel

\begin{tabular}{cclccc}
\hline No & Variabel & Definisi Operasional Variabel (DOV) & Sumber & Skala \\
\hline 1 & Pengetahuan & $\begin{array}{l}\text { Segala sesuatu yang diketahui tentang } \\
\text { fatwa MUI no 4 tahun 2014 tentang } \\
\text { pelestarian satwa langka berdasarkan } \\
\text { hasil yang telah dipelajari } \\
\text { Suatu proses untuk membuat penilaian } \\
\text { kesan mengenai fatwa konservasi satwa } \\
\text { langka }\end{array}$ & Likert \\
& Persepsi & Likert \\
& Sikap & $\begin{array}{l}\text { Kesiapan untuk bereaksi terhadap suatu } \\
\text { objek dalam bertindak melindungi satwa } \\
\text { langka untuk keseimbangan ekosistem } \\
\text { Keingin seseorang untuk melakukan aksi } \\
\text { konservasi satwa langka }\end{array}$ & Survei & Likert \\
& Niat & & & \\
\hline
\end{tabular}


1813 Pengetahuan, Persepsi dan Sikap Masyarakat Terhadap Keinginan untuk melakukan Konservasi Hewan Liar yang Terancam Punah - Mutiara Selni , Fachruddin M. Mangunjaya, Gugah Praharawati, Yeremiah Rubin Tjamin, Bahagia

DOI: https://doi.org/10.31004/edukatif.v3i4.579

Teknik yang digunakan yaitu skala likert. Menurut Sugiono (2010) skala likert digunakan untuk mengukur sikap, pendapat dan persepsi seseorang tentang fenomena sosial. Dalam skala likert variabel yang dapat diukur akan dijabarkan menjadi indikator variabel, kemudian indikator dijadikan sebagai titik tolak ukur menyusun item-item instrumen yang dapat berupa pernyataan. Adapun cara kerja yang dilakukan meliputi sampling populasi dilakukan secara purposive sampling dengan menggunakan kuisioner dengan skala Likert Allen \& Seaman (2007), terdapat satu kuisioner yang akan diberikan kode berbeda sebelum disebarkan kepada masyarakat desa, Kuisioner desa Intervensiakan diberi kode A dan kuisioner desa non intervensi akan diberi kode B, kuisioner disebarkan kepada masyarakat desa yang sudah di sosialisasikan maupun kepada masyarakat yang desanya belum disosialisasikan tentang fatwa MUI no 04 tahun 2014, jawaban kuisioner ditabulasikan kedalam 4 tabel dengan skala 1 untuk sangat tidak setuju (STS) dan tidak setuju (TS), serta skala 2 untuk setuju (S) dan sangat setuju (SS), Setelah ditabulasikan data dikonversikan kedalam SPSS 22.0 untuk memulai analisis data dengan uji t berpasangan.

Data yang telah didapatkan dilakukan analisis. Data dimasukan ke dalam microsoft excel berupa angka dengan besaran 1-4 untuk memiliki jawaban "sangat tidak setuju" (STS) hingga " sangat setuju" (SS). Kemudian data tersebut akan dilakukan pengolahan ke dalam SPSS dengan menghitung total nilai baik. Nilai baik adalah nilai yang terdiri dari jumlah nilai "setuju"(S) dan "sangat setuju" (SS), sedangkan nilai tidak baik adalah nilai yang terdiri dari jumlah nilai "sangat tidak setuju" (STS) dan nilai "tidak setuju" (TS). Kemudian dihitung pula rataan (mean) pengetahuan, persepsi dan sikap kepada setiap responden. Uji t juga untuk menentukan nilai $\mathrm{P}$ (probabilitas) pada ketiga variabel untuk mengetahui apakah hasil uji terhadap variabel tersebut bermakna terhadap niat konservasi fatwa (Alhusin, 2003).

\section{HASIL DAN PEMBAHASAN}

Masyarakat yang menjadi responden pada penelitian ini adalah yang bersedia secara sukarela mengisi kuisioner yang disebarkan di masjid dan rumah masyarakat. Kuisioner yang sudah diisi, setelah diseleksi kelengkapannya didapatkan bahwa penelitian menunjukan tingkat pendidikan yang dimiliki responden kawasan Bukit Rimbang-Baling, Riau didominasi tingkat pendidikan SMA sederajat dibandingkan dengan tingkat pendidikan tidak pernah sekolah, SD, SMP dan D3/S1. Dengan tingkat persentase (41.5\%) yang diantaranya didominasi 96 responden laki-laki dan 57 responden perempuan (tabel 3). Hasil dari analisis uji chi-square pada tabel lampiran 9 menunjukan hubungan antara jenis kelamin dengan pendidikan tidak memiliki makna atau tidak signifikan $(\mathrm{p}>0.05$ ), hal ini dikarenakan pendidikan yang tinggi seperti SMA sederajat belum diprioritaskan pada kaum perempuan di wilayah daerah karena hanya kaum laki-laki yang dianggap dapat memenuhi tingkat kebutuhan perekonomian (Hartanto, 2010).

Tabel 2. Hubungan jenis kelamin dengan pendidikan

\begin{tabular}{cccccccc}
\hline & & $\begin{array}{c}\text { Tidak } \\
\text { pernah } \\
\text { sekolah }\end{array}$ & SD & $\begin{array}{c}\text { Pendidikan } \\
\text { SMP }\end{array}$ & SMA & D3/S1 & Total \\
\hline Jenis Kelamin & Laki-laki & 2 & 61 & 39 & 96 & 21 & 219 \\
\multicolumn{2}{c}{ Total } & 6 & 35 & 40 & 57 & 12 & 150 \\
& 8 & 96 & 79 & 153 & 33 & 369 \\
\hline
\end{tabular}

Dalam penelitian ini di kawasan Bukit Rimbang-Baling, Riau jenis pekerjaan responden yang dominan yaitu sebagai petani dengan pendapatan sekitar 500.000-1.000.000 perbulan (tabel 4) yang dikategorikan 
1814 Pengetahuan, Persepsi dan Sikap Masyarakat Terhadap Keinginan untuk melakukan Konservasi Hewan Liar yang Terancam Punah - Mutiara Selni , Fachruddin M. Mangunjaya, Gugah Praharawati, Yeremiah Rubin Tjamin, Bahagia

DOI: https://doi.org/10.31004/edukatif.v3i4.579

masuk ke dalam golongan pendapatan rendah karena dibawah penghasilan rata-rata (Hartanto, 2010). Karena banyaknya perkebunan kelapa sawit dan karet yang memungkinkan banyaknya masyarakat yang memilih pekerjaan sebagai petani dibandingkan dengan pekerjaan yang lainnya. Hal ini juga dapat dibuktikan dengan adanya analisis uji chi square pada tabel lampiran 10 antara hubungan pekerjaan dengan pendapatan yang memiliki arti bermakna atau signifikan $(\mathrm{p}<0.00)$ karena jenis pekerjaan seseorang sangat mempengaruhi faktor pendapatan yang nantinya akan digunakan sebagai kebutuhan ekonomi orang tersebut (Cahyono et al., 2006).

Tabel 3. Hubungan pekerjaan dengan pendapatan

\begin{tabular}{cccccccc}
\hline & & & \multicolumn{2}{c}{ Rupiah } & Total \\
& & Rupiah & $\begin{array}{c}500000- \\
1000000 \\
\text { Rupiah }\end{array}$ & $\begin{array}{c}1000000- \\
2000000 \\
\text { Rupiah }\end{array}$ & $\begin{array}{c}2000000- \\
400000 \\
\text { Rupiah }\end{array}$ & $\begin{array}{c}>40000 \\
00 \\
\text { Rupiah }\end{array}$ \\
\hline Pekerjaan & PNS & 1 & 1 & 6 & 7 & 7 & 22 \\
& Pegawai & 5 & 2 & 11 & 15 & 8 & 41 \\
& Swasta & & & & & & \\
& Petani & 32 & 77 & 47 & 46 & 10 & 212 \\
& Pedagang & 5 & 7 & 4 & 5 & 2 & 23 \\
& Lainnya & 33 & 19 & 14 & 2 & 3 & 71 \\
& Total & 76 & 106 & 82 & 75 & 30 & 369 \\
\hline
\end{tabular}

Hasil dari penelitian karakteristik responden antara etnis suku dengan usia di dominasi oleh etnis suku melayu, karena adanya perpindahan ibu kota Provinsi Riau dari Tanjung Pinang ke Pekanbaru dengan ratarata usia responden 21-30 tahun sebanyak 111 dari 369 (tabel 5). Berdasarkan data badan pusat statistik Hartanto (2010), kelompok penduduk umur 0-14 tahun dianggap sebagai kelompok yang belum produktif secara ekonomi, kelompok penduduk umur 15-64 tahun sebagai kelompok yang produktif dan kelompok penduduk umur 64 tahun ke atas sebagai kelompok yang tidak lagi produktif.

Hal ini sesuai dengan hasil analisa dari uji chi square pada tabel lampiran 11 yang menunjukan hubungan atara suku bangsa dan usia tidak bermakna atau tidak signifikan ( $\mathrm{p}<0.05$ ), karena perbedaan keragaman suku bangsa di Indonesia yang sangat luar biasa dengan faktor usia responden tidak mempengaruhi isi dari data responden pada penelitian ini karena fokus utama yang ingin dilihat yaitu niat masyarakat terhadap konservasi satwa langka.

Tabel 4. Hubungan suku dengan usia

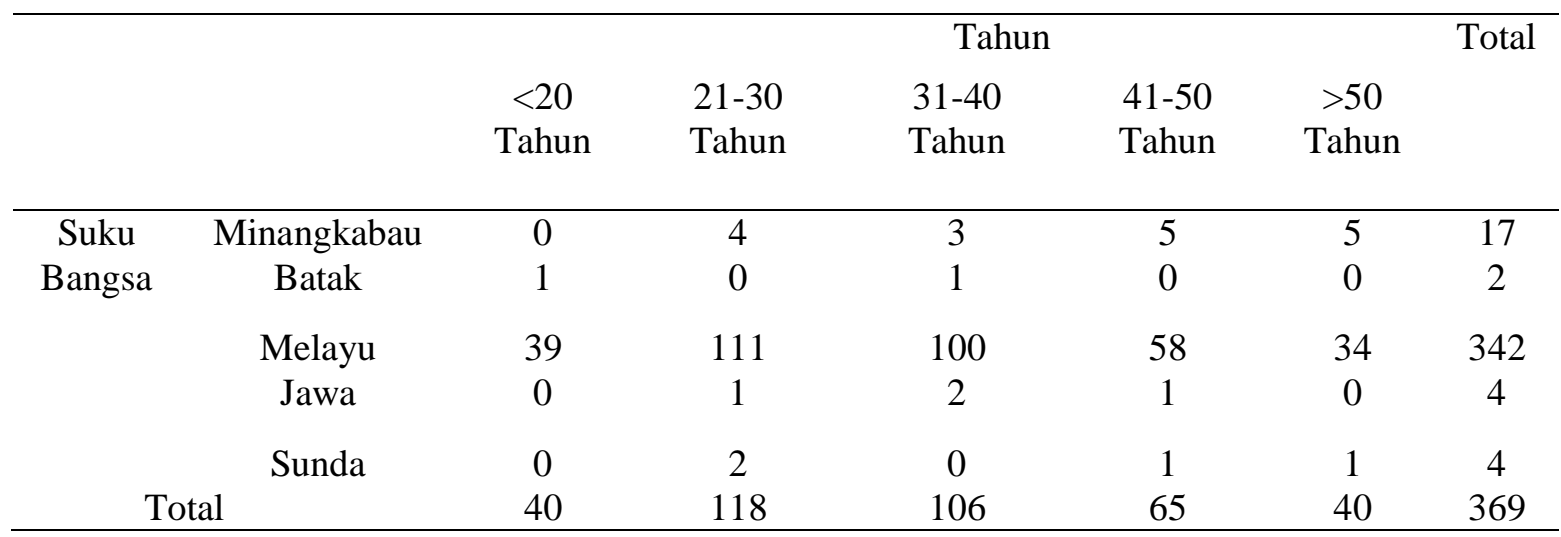


1815 Pengetahuan, Persepsi dan Sikap Masyarakat Terhadap Keinginan untuk melakukan Konservasi Hewan Liar yang Terancam Punah - Mutiara Selni , Fachruddin M. Mangunjaya, Gugah Praharawati, Yeremiah Rubin Tjamin, Bahagia

DOI: https://doi.org/10.31004/edukatif.v3i4.579

Berdasarkan hasil data penelitian dapat dilihat (Gambar 2) banyak masyarakat yang memperoleh informasi pengetahuan mengenai fatwa MUI No 04 tahun 2014 dari ceramah para ustadz dengan persentase sebesar $54.5 \%$ melalui khotbah yang sering disampaikan ustadz dimasjid karena banyaknya masyarakat yang antusias terhadap isi dari ceramah yang diberikan oleh para ustadz. Ketiga melalui media sosial dengan persentase $6.5 \%$, karena dengan kemajuan teknologi yang semakin berkembang media sosial menjadi sumber informasi yang dapat diakses oleh semua masyarakat. Keempat melalui pembicaraan masyarakat ke masyarakat lainnya dengan persentase $3.5 \%$ dan sisanya $16 \%$ masyarakat yang belum mengetahui tentang informasi mengenai fatwa MUI.

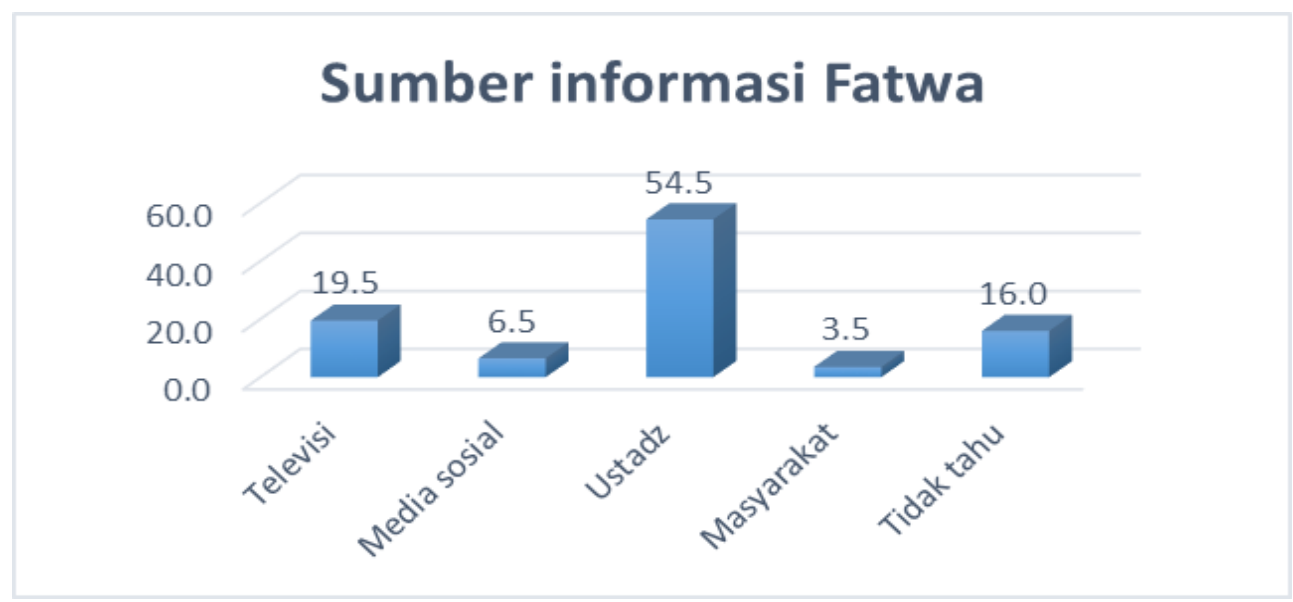

Gambar 2. Sumber pengetahuan terhadap fatwa

Berdasarkan hasil data penelitian dapat dilihat (Gambar 3) banyak masyarakat yang lebih mendominansi untuk mematuhi peraturan syariat agama seperti fatwa dengan persentase sebesar $79.7 \%$, karena mayoritas masyarakat banyak yang beragama muslim yang sangat memengang teguh prinsip nilai syariat agama. Kedua banyak masyarakat yang setuju memilih kedua peraturan untuk dipatuhi dengan persentase $12.5 \%$ dan sisanya memilih peraturan pemerintah sebagai peraturan yang harus dipatuhi dengan persentase $7.9 \%$, hal ini dapat dikarenakan kurangnya sosialisasi yang dilakukan pemerintah terhadap masyarakat mengenai peraturan tentang pelestarian satwa langka.

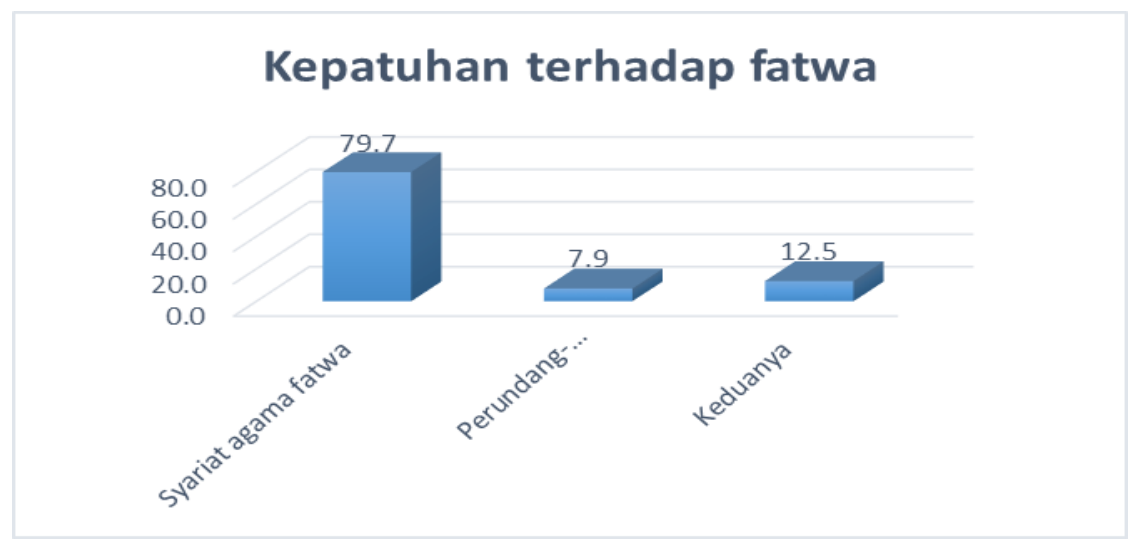

Gambar 3. Kepatuhan terhadap fatwa

Berdasarkan hasil penelitian dapat dilihat (Gambar 4) bahwa tokoh ustadz sangat bepengaruh terhadap pemahaman masyarakat terhadap niat konservasi satwa langka dengan persentase sebanyak $55.3 \%$, karena 
1816 Pengetahuan, Persepsi dan Sikap Masyarakat Terhadap Keinginan untuk melakukan Konservasi Hewan Liar yang Terancam Punah - Mutiara Selni , Fachruddin M. Mangunjaya, Gugah Praharawati, Yeremiah Rubin Tjamin, Bahagia

DOI: https://doi.org/10.31004/edukatif.v3i4.579

peran ustadz yang dapat memberikan pemahaman mengenai edukasi ilmu pengetahuan tentang konservasi satwa langka dibandingkan dengan tokoh yang lainnya. Kedua tokoh yang lebih berpengaruh yaitu peran masyarakat itu sendiri dengan persentase sebanyak $31.4 \%$, karena adanya informasi yang bersumber dari satu masyarakat ke masyarakat lainnya. Ketiga pemerintah daerah yang berpengaruh terhadap masyarakat dengan persentase $12.2 \%$, dan yang sedikit berpengaruh terhadap informasi pengetahuan tentang satwa langka yaitu presiden RI dengan persentase $1.1 \%$.

\section{Tokoh yang berpengaruh}

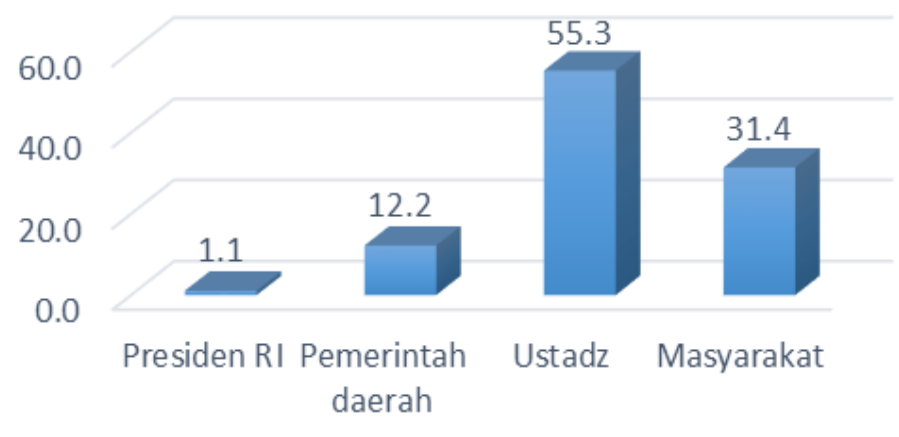

Gambar 4. Tokoh yang berpengaruh

Hasil penelitian menunjukan bahwa pengetahuan masyarakat Bukit Rimbang-Baling umumnya masuk ke dalam kategori baik (94\%), bahkan 33.6\% diantaranya masuk kategori sangat baik, walaupun masih ada yang masuk ke dalam kategori cukup 6\% (tabel 6). Niat mempunyai peran yang penting dalam sebuat aksi sedangkan pengetahuan yang baik ini dapat terjadi bukan karena hanya tingkat pendidikan yang relatif baik (41.5\% berpendidikan minimal SMA) tetapi juga karena kehadiran organisasi LSM yang beraktivitas di Bukit Rimbang-Baling, Riau.

Tabel 5. Hubungan pengetahuan dan niat konservasi

\begin{tabular}{ccccccc}
\hline & & $\begin{array}{c}\text { Sangat } \\
\text { kurang }\end{array}$ & $\begin{array}{c}\text { Cukup } \\
\text { Pengetahuan }\end{array}$ & Baik & $\begin{array}{c}\text { Sangat } \\
\text { baik }\end{array}$ & Total \\
& Cukup & 3 & 3 & 12 & 4 & $22(6 \%)$ \\
& Baik & 0 & 4 & 171 & 48 & $223(60.4 \%)$ \\
& Sangat Baik & 0 & 0 & 44 & 80 & $124(33.6 \%)$ \\
& Total & 3 & 7 & 227 & 132 & 369 \\
\hline
\end{tabular}

Analisis hasil uji chi-square antara hubungan pengetahuan dan niat konservasi menghasilkan hubungan yang bermakna atau signifikan $(\mathrm{p}<0.00$ ). Pengetahuan merupakan "Tahu" yang terjadi setelah orang melakukan penginderaan terhadap objek tertentu yang terjadi melalui panca indera manusia yakni indera pengelihatan, pendengaran, penciuman, rasa dan raba yang sebagian besar pengetahuan manusia diperoleh melalu mata dan telinga (Notoatmodjo, 2003). Dalam penelitian ini masyarakat Rimbang Baling mengetahui niat terhadap konservasi satwa langka dengan penginderaan pengelihatan dari tulisan buku maupun media massa serta melalui pendengaran dari ceramah para ustadz dimasjid dan pembicaraan diskusi masyarakat dengan masyarakat lainnya. Hasil ini memberi arti bahwa niat berperan dalam aksi konservasi terkait dengan 
1817 Pengetahuan, Persepsi dan Sikap Masyarakat Terhadap Keinginan untuk melakukan Konservasi Hewan Liar yang Terancam Punah - Mutiara Selni , Fachruddin M. Mangunjaya, Gugah Praharawati, Yeremiah Rubin Tjamin, Bahagia

DOI: https://doi.org/10.31004/edukatif.v3i4.579

pengetahuan masyarakat di sekitar Bukit Rimbang-Baling, Riau. Dapat disimpulkan bahwa niat berperan dalam aksi konservasi terjadi karena pengetahuan yang baik. Hasil penelitian menunjukan bahwa persepsi masyarakat Bukit Rimbang-Baling, Riau umumnya adalah baik (91.6\%) bahkan (19.8\%) diantaranya masuk ke dalam kategori sangat baik, hanya (0.3) masuk ke kategori sangat kurang dan (8.1\%) masuk ke kategori kurang (tabel 7). Persepsi yang baik ini perlu dipertahankan sehingga masyarakat yang masih berperilaku sangat kurang dan kurang dapat berubah menjadi

Tabel 6. Hubungan Persepsi dan niat konservasi

\begin{tabular}{ccccccc}
\hline & $\begin{array}{c}\text { Sangat } \\
\text { kurang }\end{array}$ & $\begin{array}{c}\text { Niat } \\
\text { Cukup }\end{array}$ & Baik & $\begin{array}{c}\text { Sangat } \\
\text { baik }\end{array}$ & Total \\
\hline Persepsi & Sangat kurang & 0 & 0 & 1 & 0 & $1(0.3 \%)$ \\
& Kurang & 3 & 4 & 18 & 5 & $30(8.1 \%)$ \\
& Baik & 0 & 3 & 188 & 74 & $265(71.8 \%)$ \\
& Sangat Baik & 0 & 0 & 20 & 53 & $73(19.8 \%)$ \\
& Total & 3 & 7 & 227 & 132 & 369 \\
\hline
\end{tabular}

Persepsi adalah suatu proses untuk membuat penilaian untuk membangun kesan terhadap berbagai macam hal (Pahlevi, 2007). Dalam analisis hasil uji chi square antara hubungan persepsi dengan niat konservasi menghasilkan hubungan yang sangat bermakna atau signifikan $(\mathrm{p}<0.00)$, seperti halnya pengetahuan hasil ini juga memberi arti bahwa niat berperan dalam aksi konservasi terkait sangat erat dengan persepsi masyarakat di sekitar Bukit Rimbang-Baling, Riau. Dapat disimpulkan bahwa niat berperan dalam aksi konservasi masyarakat Bukit Rimbang-Baling, Riau semakin meningkat sejalan dengan adanya peningkatan persepsi yang baik. Persepsi yang baik akan diikuti oleh niat aksi konservasi yang baik.

Penelitian ini sesuai dengan hasil penelitian yang dilakukan oleh Prawira et al. (2017) yang berjudul "Pengaruh Sosialisasi Fatwa MUI No 4 tahun 2014 Tentang Pelestarian Satwa Langka Terhadap Tingkat Pengetahuan, Persepsi dan Preferensi Masyarakat di Kaeasan Penyangga Taman Nasional Ujung Kulon Banten" yang menunjukan peningkatan terhadap variabel persepsi masyarakat.

\section{A. Hubungan sikap dengan niat konservasi}

Hasil penelitian menunjukan bahwa sikap masyarakat Bukit Rimbang-Baling, Riau umumnya masuk dalam kategori baik yaitu (94.3\%) bahkan (32.2\%) masuk ke dalam kategori sangat baik, walupun masih ada (0.3\%) masuk ke kategori sangat kurang dan (5.4\%) masuk ke dalam kategori cukup (tabel 5). Niat mempunyai peran yang penting dalam sebuah aksi, sedangkan sikap merupakan sebuah prinsip yang dipegang oleh responden dalam melihat respon tentang keadaan (Ajzen, 1991).

Tabel 7. Hubungan sikap dengan niat konservasi

\begin{tabular}{|c|c|c|c|c|c|c|}
\hline \multicolumn{7}{|c|}{ Niat } \\
\hline & & $\begin{array}{l}\text { Sangat } \\
\text { kurang }\end{array}$ & Cukup & Baik & $\begin{array}{c}\text { Sangat } \\
\text { baik }\end{array}$ & Total \\
\hline \multirow[t]{5}{*}{ Sikap } & Sangat kurang & 1 & 0 & 0 & 0 & $1(0.3 \%)$ \\
\hline & Kurang & 2 & 4 & 14 & 0 & $20(5.4 \%)$ \\
\hline & Baik & 0 & 3 & 166 & 60 & $229(62.1 \%)$ \\
\hline & Sangat Baik & 0 & 0 & 47 & 72 & $119(32.2 \%)$ \\
\hline & Total & 3 & 7 & 227 & 132 & 369 \\
\hline
\end{tabular}

Analisis hasil uji chi-square antara hubungan sikap dengan niat berperan dalam aksi konservasi satwa langka menghasilkan hubungan yang bermakna atau signifikan $(\mathrm{p}<0.00)$. Sikap merupakan gambaran atas tindakan afektif yang bersifat positif, negatif atau netral untuk respon senang atau tidak senang, menerima 
1818 Pengetahuan, Persepsi dan Sikap Masyarakat Terhadap Keinginan untuk melakukan Konservasi Hewan Liar yang Terancam Punah - Mutiara Selni , Fachruddin M. Mangunjaya, Gugah Praharawati, Yeremiah Rubin Tjamin, Bahagia

DOI: https://doi.org/10.31004/edukatif.v3i4.579

atau menolak, setuju atau tidak setuju pada konsep tertentu Hafizd et al. (2017). Dalam hal ini masyarakat Rimbang Baling sangat merespon dengan baik dan setuju untuk bersikap ikut andil terhadap niat aksi konservasi satwa langka untuk menjaga keseimbangan ekosistem. Hasil ini memberikan arti bahwa niat berperan dalam aksi konservasi terkait dengan sikap masyarakat. Dapat disimpulkan bahwa niat yang baik membawa sikap masyarakat menjadi baik

Ketiga variabel independen (Pengetahuan, persepsi dan sikap) di suaka margasatwa Bukit RimbangBaling, Riau diseleksi dan diolah untuk menilai akumulasi peran terhadap peningkatan niat berpartisipasi dalam konservasi. Hasil dari pengetahuan, persepsi dan sikap yang digunakan hanya yang masuk dalam kategori baik dan sangat baik untuk menilai hubungan adanya pengetahuan, persepsi dan sikap yang sudah baik dengan niat berpartisipasi dalam konservasi pada masyarakat Rimbang-Baling, Riau (tabel 9).

Tabel 8. Hubungan pengetahuan, persepsi dan sikap terhadap niat konservasi

\begin{tabular}{ccccc}
\hline Kategori & & \multicolumn{2}{c}{ Niat (\%) $(\mathbf{n = 3 6 9 )}$} \\
& Kurang & Cukup & Baik & Sangat Baik \\
\hline Pengetahuan & 0 & $22(6 \%)$ & $223(60.4 \%)$ & $124(33.6 \%)$ \\
Persepsi & $1(0.3 \%)$ & $30(8.1 \%)$ & $265(71.8 \%)$ & $73(19.8 \%)$ \\
Sikap & $1(0.3 \%)$ & $20(5.4 \%)$ & $229(62.1 \%)$ & $119(32.2 \%)$ \\
Rata-rata \% & $0.2 \%$ & $6.5 \%$ & $64.7 \%$ & $28.5 \%$ \\
\hline
\end{tabular}

Hasil dari tabel 9 dapat dilihat bahwa berdasarkan variabel pengetahuan, persepsi dan sikap yang tergolong masuk ke kategori baik (baik dan sangat baik), maka niat berpartisipasi masyarakat Bukit Rimbangbaling, Riau umumnya masuk ke dalam kategori baik (93.2\%) bahkan 28.5\% masuk ke dalam kategori sangat baik dan hanya sekitar (6.5\%) yang masuk ke dalam kategori cukup. Hasil penelitian ini mengindikasikan adanya masyarakat Bukit Rimbang-Baling, Riau yang sudah mempunyai niat yang sangat baik dalam berpartisipasi dalam konservasi satwa langka untuk keseimbangan ekosistem.

Hasil analisis regresi linier berganda menunjukan hubungan antara pengetahuan, persepsi dan sikap terhadap niat konservasi satwa langka sangat bermakna $(\mathrm{p}<0.01)$, sementara intervensi terhadap niat menunjukan hubungan tak bermakna $(\mathrm{p}>0.05)$. Pola hubungan antara variabel tersebut tergambar dalam persamaan regresi sebagai berikut :

\section{Niat $=0.206$ Pengetahuan +0.250 persepsi +0.264 sikap}

Pola hubungan antara ketiga variabel (pengetahun, persepsi dan sikap) terhadap niat berperan aksi konservasi berdasarkan analisis regresi berganda hanya terjadi antara pengetahuan, persepsi dan sikap. Berdasarkan pola hubungan tersebut dapat dijelaskan secara matematis bahwa peningkatan satu kategori pengetahuan ke arah yang lebih baik akan meningkatkan $20.6 \%$, niat berperan dalam aksi konservasi peningkatan satu kategori persepsi ke arah yang lebih baik akan meningkat $25 \%$, niat berperan dalam aksi konservasi peningkatan satu kategori sikap ke arah yang lebih baik akan meningkat $26.4 \%$. Berdasarkan persamaan regresi tercermin bahwa pola urutan tertinggi dalam kaitan dengan niat aksi konservasi di Bukit Rimbang-baling, Riau dapat dipetakan yaitu niat berkaitan lebih erat dengan sikap dibandingkan dengan pengetahuan dan persepsi. Oleh karena itu, intervensi yang dilakukan dalam melakukan program konservasi dalam prioritas menurut TPB di Bukit Rimbang-Baling, Riau adalah melalui pendekatan pembinaan melalui sikap yang diikuti oleh pembinaan pengetahuan dan persepsi.

Masyarakat Bukit Rimbang-Baling sudah mempunyai pengetahuan, persepsi dan sikap yang tergolong baik terhadap niat berperan aksi konservasi satwa langka. Hal ini dapat terjadi karena masyarakat dapat 
1819 Pengetahuan, Persepsi dan Sikap Masyarakat Terhadap Keinginan untuk melakukan Konservasi Hewan Liar yang Terancam Punah - Mutiara Selni , Fachruddin M. Mangunjaya, Gugah Praharawati, Yeremiah Rubin Tjamin, Bahagia

DOI: https://doi.org/10.31004/edukatif.v3i4.579

merasakan manfaat dari kehadiran suaka margasatwa Bukit Rimbang-Baling, Riau dan bisa dikarenakan adanya pembinaan yang dilaksanakan secara terus-menerus. Namun pembinaan masih perlu dilaksanakan secara konsisten dan berkelanjutan agar niat masyarakat dalam aksi konservasi satwa langka terus meningkat. Pembinaan yang direkomendasikan untuk terus dilaksanakan berkaitan dengan pengetahuan dan persepsi, sedangkan sikap yang sudah tergolong baik merupakan modal utama dalam berinteraksi secara sosial pada penelitian ini tidak terbukti terkait dengan niat berpartisipasi dalam aksi konservasi satwa langka.

\section{KESIMPULAN DAN SARAN}

Dari hasil penelitian diatasi maka ada beberapa aspek penting yang bisa disimpulkan diantaranya pengetahuan masyarakat berperan positif terhadap niat konservasi lingkungan dan satwa liar yang terancam punah sehingga masyarakat akan tetap menjaga lingkungan karena mengetahui dampak kepunahan terhadap kehidupan manusia. Kemudian, sikap masyarakat sangat positif terhadap fatwa ulama yang sebagai langkah secara agama untuk menyelamatkan kehidupan hewan liar dan lingkungan sehingga masyarakat mendukung atau senang dengan adanya fatwa tersebut untuk menjaga lingkungan. Pada akhirnya masyarakat berkeinginan untuk melakukan aktivitas konservasi lingkungan dan satwa liar. Selain itu, masyarakat memiliki persepsi yang positif karena memandang bahwa kerusakan dan punahan hewan liar sangat penting sehingga masyarakat berpandangan bahwa fatwa ulama sangat penting.

Untuk itu persepsi, pengetahuan dan sikap masyarakat berperangaruh secara positif terhadap fatwa ulama yang berfokus kepada penyelamatan lingkungan termasuk degredasi lingkungan dan potensi kehilangan hewan liar. Berdasarkan kesimpulan yang telah diperoleh dari hasil penelitian, maka ada saran yang penulis berikan yang berhubungan dengan penelitian pengetahuan, persepsi dan sikap. Saran untuk penelitian selanjutnya, penelitian ini dapat dilakukan kembali dengan objek penelitian yang berbeda serta dengan item pertanyaan pada kuisioner yang berbeda dengan pertanyaan kuesioner penelitian lainnya. Bagi peneliti selanjutnya dapat dimanfaatkan sebagai bahan rujukan dalam melakukan penelitian yang berkaitan dengan niat konservasi satwa langka berdasarkan fatwa MUI No 04 tahun 2014 tentang pelestarian ekosistem.

\section{DAFTAR PUSTAKA}

Allen, I. E., \& Seaman, C. A. (2007). Skala likert dan analisis data. Kemajuan Kualitas, 40(7), 64-65.

Bahagia, B., Wibowo, R., Mangunjaya, F. M., \& Priatna, O. S. (2020). Traditional Knowledge of Urug Community for Climate, Conservation, and Agriculture. MIMBAR: Jurnal Sosial Dan Pembangunan, $36(1), 240-249$.

Cahyono, S. A., Jariyah, N. A., \& Indrajaya, Y. (2006). Karakteristik Sosial Ekonomi Yang Mempengaruhi Pendapatan Rumah Tangga Penyadap Getah Pinus di Desa Somagede, Kebumen, Jawa Tengah. Jurnal Penelitian Sosial Dan Ekonomi Kehutanan, 3(2), 147-159.

Clements, R., Foo, R., Othman, S., Rahman, U., \& Mustafa, S. R. S. (2009). Islam, Konservasi Penyu, dan Masyarakat Pesisir. Biologi Konservasi, 23(3), 516-517.

Digdi, A. A., Putriraya, A., Wijayanto, A., \& Cahyono, T. (2015). Socioeconomic Assessment of People in and aroundo Rimbang-Baling Wildlife Reserve. In Community Empowerment and Conservation Education Association (YAPEKA).

FAO, \& JRC. (2012). Perubahan penggunaan lahan hutan global 1990-2005. Makalah Kehutanan FAO No. 169.

Gade, A. M. (2015). Islamic Law and The Environment in Indonesia. Pandangan Dunia: Agama, Budaya, Dan Ekologi Global, 19(2), 161-183. 
1820 Pengetahuan, Persepsi dan Sikap Masyarakat Terhadap Keinginan untuk melakukan Konservasi Hewan Liar yang Terancam Punah - Mutiara Selni , Fachruddin M. Mangunjaya, Gugah Praharawati, Yeremiah Rubin Tjamin, Bahagia

DOI: https://doi.org/10.31004/edukatif.v3i4.579

Hafizd, T. A., Mangunjaya, F. M., \& Camin, Y. R. (2017). Tingkat Persepsi dan Kesadaran Masyarakat Desa Tanjung Beringin Terhadap Fatwa Satwa MUI No 4 Tentang Perlindungan Satwa Langka untuk Keseimbangan Ekosistem. Jurnal Himmah, 1(1), 53-67.

Hartanto, W. (2010). Sensus Penduduk Indonesia 2010. Badan Pusat Statistik/BPS.

I, A. Y. (2011). Pengelolaan Lingkungan dan Keanekaragaman Hayati dalam Perspektif Islam (P. KIM (ed.)).

IUCN. (2016). The IUCN Red List of Threatened Species.

Kremen, C., Niles, J. O., Dalton, M., Daily, G. C., Ehrlich, P. R., Fay, J. P., \& Grewal, D. (2000). Economic incentives for rain forest conservation across scales. Sains, 2888(5472), 1828-1832.

Mangunjaya, F. M. (2011). Developing Environmental Awareness and Conservation Through Islamic Teaching. Jurnal Studi Islam, 22(1), 36-49.

Mangunjaya, F. M. (2019). Konservasi Alam dalam Islam edisi revisi. Yayasan Pustaka Obor Indonesia.

Mangunjaya, F. M., \& McKay, J. E. (2012). Reviving an Islamic Approach for Environmental Conservation in Indonesia. Pandangan Dunia: Agama, Budaya, Dan Ekologi Global, 16(3), 286-305.

McKay, J. E. (2013). Integrating Religion within Conservation: Islamic Beliefs and Sumatran Forest Management. Universitas Kent.

Measey, M. (2010). Indonesia: a vulnerable country in the face of climate change. Jurnal Elektronik Mayoritas Global, 1(1), 31-45.

MUI, Prabowo, H. S., Tobing, I. S., Abbas, A. S., \& Chairul. (2017). Pelestarian Satwa Langka untuk Keseimbangan Ekosistem: Penuntun Sosialisasi Fatwa MUI No 4, 2014, tentang Fatwa Pelestarian Satwa Langka untuk Menjaga Keseimbangan Ekosistem. LPLH-SDA MUI.

Notoatmodjo, S. (2003). Pendidikan dan perilaku kesehatan. Rineka Cipta.

Pahlevi, T. (2007). Persepsi masyarakat terhadap Taman Wisata Alam Sicikeh-Cikeh (Studi Kasus di Dusun Pancur Nauli, Desa Lae Hole II, Kec. Parbuluan, Kab. Dairi, Sumatera Utara). Universitas Sumatera Utara.

Prawira, E. Y., Camin, Y. R., \& Mangunjaya, F. M. (2017). Pengaruh Sosialisasi Fatwa MUI No 4 Tahun 2014 Tentang Pelestarian Satwa Langka Terhadap Tingkat Pengetahuan, Persepsi, dan Preferensi Mayarakat di Kawasan Penyangga Taman Nasional Ujung Kulon. Jurnal Himmah, 1(1), 37-52.

Sriyanto. (n.d.). Kajian Mangsa Harimau Sumatera (Panthera tigris sumatrae, Pocock 1929) di Taman Nasional Way Kambas. Institut Pertanian Bogor.

Sugiyono. (2010). Metode Penelitian Kuantitatif, Kualitatif, dan R\&D. Alfabeta.

UNAS, P. (2021). Ketua Ppi Unas Ajak Lakukan Konservasi Lingkungan Dari Perspektif Islam. Pusat Pengajian Islam Universitas Nasional. 